Original Article

\title{
Use of biotherapic in the control of natural infestation by Boophilus microplus: pilot study
}

\author{
Nilceu Lemos Silva; José Luiz Moletta; Alessandro Pelegrine Minho; \\ Laerte Francisco Filippsen
}

\author{
Department of Animal Health; Department of Animal Nutrition, Instituto Agronômico do \\ Paraná - IAPAR, Ponta Grossa, Paraná, Brazil
}

\begin{abstract}
In the control of tick-borne disease (TBD), resistance to chemical products has been reported and a concern with the preservation of the environment requires alternative procedures to control infestation by Boophilus microplus worldwide. The use of biotherapic preparations is one of such alternatives. The aim of this study was to evaluate the effects of a biotherapic mixture including B. microplus in naturally infested cattle. 27 animals were divided in 3 groups ( $=9)$ : I - control, received no treatment; II- treated with amitraz dip; III- treated with a standard commercial mixture of biotherapic $12 \mathrm{CH}$, p.o. Group III presented a statistically significant decrease of ticks when compared to the control group $(\mathrm{p}<0.05)$. There was no statistically significant difference between groups II (amitraz) and III (biotherapic) $(\mathrm{p}<0.05)$. These results suggest that biotherapic preparations might be an effective in the control of $B$. microplus in cattle.
\end{abstract}

Key words: Biotherapic; Tick; Alternative control; Cattle.

\section{Introduction}

Boophilus microplus (Canestrini) is a major cause of concern in the health of cattle in tropical and subtropical areas [1]. Besides wasting and transmission of pathogenic microorganisms including protozoa, rickettsias, spirochetes and virus [2], it may cause significant financial loss due to the devaluation of the leather. In Brazil, $B$. microplus finds favorable climatic conditions for its development from the Southern border to the Northern and Northeastern areas, which allow 3, 4 and potentially even 5 generations to complete their cycle in one year in areas with mean temperature above $17^{\circ} \mathrm{C}[3]$.

The effectiveness of chemical pesticides is restricted and besides the induction of resistance, they leave residues on animal products and subproducts. Resistance to B. microplus is attributed to several mechanisms, including decrease in the absorption of the pesticide, increase in its metabolization through esterases, oxidases and glutation-transferases and structural modifications in the target [4].
Moreover, the chemical treatment aims at eliminating the ectoparasites without any consideration for public health and environmental hazards. Alternative treatments are, thus, being sought for. Treatments with highly diluted and agitated substances ("homeopathic remedies") may be used according to different methodological guidelines: similarity between their effects on healthy individuals and the symptoms of the actual disease (homeopathy) or targeting the etiological agent of the disease (isopathy). In the latter case, the remedies are prepared through dilution and agitation of the etiological agent (biotherapic). Several studies attest to the effectiveness of the latter approach, including cattle diseases $[5,6,7]$.

According to Arenales et al. [8], a commercial biotherapic mixture was effective in the control of ecto and endoparasitoses in cattle. The present study aimed at evaluating the effectiveness of this biotherapic mixture in the control of the natural infestation with $B$. microplus.

Materials and methods 
The study population included 27 Purunã heifers (a race developed by Instituto Agronômico do Paraná, IAPAR), age 12-14 months, newly weaned. Animals were range grown and supplemented with concentrate (corn and soy-bran) and mineral salt according to the species requirements, $1.5 \mathrm{~kg} /$ day.

The animals were divided into 3 groups $(n=9): 1)$ control, received no treatment (GI); 2) treated with amitraz (GII); 3) treated with biotherapic (GIII). The study lasted 12 months.

Amitraz was employed by dip, bath tub containing 1 liter amitraz/1000 4 times during the experiment in the warmest season; minimum interval was 21 days.

GIII received the biotherapic mixture (Arenales Fauna \& Flora) containing Boophilus microplus, Amblyomma cajennense, Haematobia irritans, Musca domestica, Bunostomum sp, Haemonchus contortus, Haemonchus placei, Nematodirus sp, Oesophagostomum sp, Strongyloides sp, Trichostrongylus axei, Trichostrongylus colubriformis, Trichuris sp, Eimeria sp, Cysticercus cellulosae, Dermatobia hominis, all $12 \mathrm{CH}$ in a vehicle of saccharose to complete 100g. Preparation follows Farmacopéia Homeopática Brasileira [9]. The product was mixed to common mineral salt, 400 $\mathrm{g} / 25 \mathrm{~kg}$ and given to the animals with the ration, $100 \mathrm{~g} / \mathrm{d}$, corresponding to a dose of $1.6 \mathrm{~g} / \mathrm{animal} /$ day. The weight of the animals was assessed once a month.

The number of engorged B. microplus females was assessed every 14 days (total number of ectoparasites removed from heifers). Results were analyzed through general linear model (GLM), by employing SAS software, means were compared through Tukey's test $(p<0.05)$.

\section{Results}

The animals in GIII showed a reduction of $50.5 \%$ in the mean number of engorged females during the full study time, when compared to the control $(p<0.05)$. There was no statistically significant difference between GII and GIII. (Table 1)

Table 1. Experimental Results

\begin{tabular}{|c|c|c|}
\hline Treatment & $\begin{array}{c}\text { Number of engorged females } \\
\text { (mean)/year }\end{array}$ & $\begin{array}{c}\text { Weight gain } \\
\text { (kg/year) }\end{array}$ \\
\hline Control & $52,08^{\mathrm{a}}$ & $25,11^{\mathrm{a}}$ \\
\hline Amitraz & $12,67^{\mathrm{b}}$ & $30,22^{\mathrm{a}}$ \\
\hline Biotherapic & $25,71^{\mathrm{b}}$ & $45,50^{\mathrm{a}}$ \\
\hline
\end{tabular}

Different letters in a same column indicate significant difference (Tukey $\mathrm{p}<0.05$ )

Discussion
The development of resistance of Boophilus microplus to amitraz appeared worldwide 4 to 10 years after its continual use. Resistance was initially evident in Australia in 1980, where it was identified the "Ulam" strain highly resistant to amitraz and showing crossed-resistance to cymiazole and chlorimuron [10,11] Resistance may explain the similarity between the results of amitraz and biotherapic in this study $(\mathrm{p}<0.05)$, as while ideally the former ought to reduce the population of engorged females in at least $90 \%$, in our study it only did in $75.67 \%$.

Arenales et al. [8] attribute to the biotherapic commercial preparation - composed of several parasites - an adequate control of endo and ectoparasitoses in cattle, besides a weight gain $37.9 \%$ higher than in the non treated control group. However in our study, no difference was detected in the living weight among all three groups in spite of a tendency in the group treated with biotherapic preparation to gain more weight, reaching a mean increase of $20 \mathrm{~kg} / \mathrm{month}$.

\section{Conclusions}

The preparation used in this study showed significant effect in the control of the infestation with B. microplus, reducing in $50 \%$ the number of engorged females. Thus, the use of biotherapic preparations seems useful in the control of infestation in Purunã cattle.

In a comparison of susceptibility of antibiotics in bacteria isolated from daily cattle raised in organic and conventional production systems, Tikofsky et al. [12] stated that the pathogens obtained in the organic-raised animals were more susceptible to chemotherapeutic agents and therefore they presented less risk of developing resistance to drugs. Moreover, the use of phytotherapeutic agents in conventional systems of production as a part of the strategy to control parasites, may increase the useful life of drugs; [13] the same seems to be the case when biotherapic preparations are used.

Thus, the use of biotherapic preparations may decrease the number of applications of chemotherapeutic agents to animals and the selective pressure on the strains of ticks susceptible to conventional treatment; moreover, their use is allowed in organic cattle raising. On the other hand, were repetitions of the chemical agent needed, probably the odds of resistance development will be decreased if a biotherapic preparation is previously used.

\section{References}


[1] Urquhart GM, Armour J, Duncan JL, Dunn AM, Jennings FW. Parasitologia veterinária. $2^{\text {nd }}$ ed. Rio de Janeiro: Guanabara Koogan; 1998.

[2] Willadsen P, Jongjean F. Immunology of the tickhost interaction and the control of ticks and tickborne diseases. Parasitol Today. 1999; 15: 258-262.

[3] Kaufman WR. Tick-host interaction: a synthesis of current concepts. Parasitol Today. 1989; 5: 47-56.

[4] He H, Chen AC, Davey RB, Ivie GW. Molecular cloning and nucleotide sequence of a new $\mathrm{P} 450$ gene, CYP319A1, from the cattle tick, Boophilus microplus. Insect Biochem Mol Biol. 2002; 32: 303309.

[5] Silva AMCP, Schwartz FF, Cardoso MV, César AT, Sollero PA. The use of Mycoplasma spp biotherapic in dairy cattle herd. Cultura Homeopática [online]. 2005 [cited 2008 Feb]; 4(13). Available from:

http://www.feg.unesp.br/ ojs/index.php/ijhdr/article/ view/181/190

[6] Pinheiro RMK. Influência de grupo genético, condição sexual e uso de bioterápico nas características de carcaça e qualidade da carne dos bovinos de corte [Tese (Doutorado)]. Niterói: Universidade Federal Fluminense; 2007.

[7] Holmes MA, Cockcroft PD, Booth CE, Heath MF. Controlled clinical trial of the effect of a homeopathic nosode on the somatic cell counts in the milk of clinically normal dairy cows. Vet Rec. 2005; 156 (18): 565-567.
[8] Arenales MC, Morais A, Moraes F. Evaluation of the use of homeopathic products for the controlo $f$ parasites and weight gain in Indian cattle (Nelore) in Brazil. Proceedings of the XXIV World Buiatric Congress. Proceedings; 2006 October; Nice, France. Zurich: World Association for Buiatrics; 2006. 78-81.

[9] Ministério da Saúde. Farmacopéia Homeopática Brasileira. $2^{\text {nd }}$ ed. São Paulo: Atheneu; 1997.

[10] Nolan J. Current developments in resistance to amidine and pyrethroid tickicides in Australia. In: Whitehead GB, Gibson JD, editors. Tick biology and control. Grahamstown: Rhodes University; 1981. 109-114.

[11] Kemp HD, Thullner F, Gale KR, Nari A, Sabatini GA. Acaricide resistance in the cattle-ticks Boophilus microplus and B. decoloratus: review of resistance data; standardisation of resistance tests and recommendations for integrated parasite control to delay resistance. Report to the animal health services, AGAH. Rome: FAO, 1998.

[12] Tikofsky LL, Barlow JW, Santisteban C, Schukken YH. A comparison of antimicrobial susceptibility patterns for Staphylococcus aureus in organic and conventional dairy herds. Microbial Drug Resistance. 2003; 9 (Suppl 1): 39-45.

[13] Vieira LS, Cavalcante ACR. Resistência antihelmíntica em rebanhos caprinos no Estado do Ceará. Pesq Vet Bras. 1999; 19 (3): 99-103.

\section{(c)) BY-NC-ND Licensed to GIRI}

Support: authors declare that this study received no funding

Conflict of interest: authors declare there is no conflict of interest

Received: 14 February 2008; Revised: 20 March 2008; Published: 31 March 2008

Erratum: 30 Dec 2008. (http://www.feg.unesp.br/ ojs/zacha_ijhdr/erratum/?v=7\&i=22\&pi=36)

Correspondence author: Alessandro P. Minho. apminho@iapar.br ; http://www.iapar.br ; Instituto Agronômico do Paraná (IAPAR), Brazil.

How to cite this article: Silva NL, Moletta JL, Minho AP, Filippsen LF. Use of biotherapic in the control of natural infestation by Boophilus microplus: pilot study. Int J High Dilution Res [online]. 2008 [cited DD Mmm YYYY]; 7 (22): 36 38. Available from http://www.feg.unesp.br/ ojs/index.php/ijhdr/article/view/251/337. 